\title{
RESISTANCE INDUCTION IN WHEAT PLANTS BY SILICON AND APHIDS
}

\author{
Flávia Batista Gomes ${ }^{1}$; Jair Campos de Moraes ${ }^{2 *}$; Custódio Donizete dos Santos 3 ; Márcio Marcos \\ Goussain $^{1}$ \\ ${ }^{1}$ UFLA - Programa de Pós-Graduação em Agronomia/Entomologia, C.P. 3037 - 37200-000 - Lavras, MG - Brasil. \\ ${ }^{2} U F L A$ - Depto. de Entomologia. \\ ${ }^{3}$ UFLA - Depto. de Química. \\ *Corresponding author<jcmoraes@ufla.br>
}

\begin{abstract}
The pest greenbug Schizaphis graminum (Rondani) (Hemiptera: Aphididae) stands out among the factors limiting Brazilian wheat production. Chemical control is predominant in aphid management making the production dependent on insecticides. The effect of silicon and previous infestation with aphids on the induction of resistance to the greenbug was evaluated in wheat plants. Treatments consisted of control; fertilization with calcium silicate; plant infestation with aphids; fertilization with calcium silicate + plant infestation with aphids. A free-choice preference test was performed 35 days after seedling emergence; the aphid's intrinsic rate of population increase $\left(\mathrm{r}_{\mathrm{m}}\right)$ was also determined, and the activities of three enzymes (peroxidase, polyphenoloxidase, and phenylalanine ammonia-lyase) involved in plant defense were quantified. Silicon fertilization and the previous infestation with aphids induced wheat plant resistance to the greenbug. Key words: Schizaphis graminum, Triticum aestivum, pest management, induced resistance, host plant resistance
\end{abstract}

\section{INDUÇÃO DE RESISTÊNCIA EM PLANTAS DE TRIGO POR SILÍCIO E PULGÕES}

\begin{abstract}
RESUMO: Dentre os fatores limitantes da produção tritícola brasileira está o ataque de insetos-praga, podendose destacar o pulgão-das-gramíneas Schizaphis graminum (Rondani) (Hemiptera: Aphididae). O controle químico é predominante no manejo desse pulgão, tornando a produção dependente do uso de inseticidas. Este trabalho avalia o efeito do silício e da infestação prévia com pulgões na indução de resistência ao pulgão-dasgramíneas em plantas de trigo. Os tratamentos foram: testemunha; adubação com silicato de cálcio; infestação das plantas com pulgões; adubação com silicato de cálcio + infestação das plantas com pulgões. Trinta e cinco dias após emergência das plântulas foi realizado teste de preferência com chance de escolha; determinação da taxa de crescimento da população do pulgão $\left(\mathrm{r}_{\mathrm{m}}\right)$ e quantificação da atividade de três enzimas envolvidas na defesa das plantas: peroxidase, polifenoloxidase e fenilalanina amônia-liase. A adubação silicatada e a infestação prévia com pulgões induzem resistência em plantas de trigo ao pulgão-das-gramíneas.

Palavras-chave: Schizaphis graminum, Triticum aestivum, manejo de pragas, resistência induzida, resistência de plantas a insetos
\end{abstract}

\section{INTRODUCTION}

Silicon is not considered an essential element for most plants, but it has been reported that absorption of silicon is beneficial to crops, hence induces protection against pest attack (Epstein, 1994; 1999). The protection conferred to plants by silicon could be related to its accumulation and polymerization in the cells, forming a mechanical barrier that difficult the insect-pests attack (Yoshida et al., 1962). However, mechanical barriers are not the only defense mechanism against external agents. Studies with cucumber (Cucumis sativus L.) have shown enhanced resistance of silicon-treated plants to Pythium spp. and Sphaerotheca fuliginea (Schlecht.) Poll. resulting from the accumulation of phenolic compounds, lignin and phytoalexins (Chérif et al., 1992a; 1992b; 1994;
Fawe et al., 1998). However, silicon has not yet been indicated as a plant defense response elicitor against the insect attack.

Elicitors trigger the induced resistance process; they are agents that induce any defense response in the plants (Dixon et al., 1994). Increased activity of defensives enzymes such as peroxidase (POX), polyphenoloxidase (PPO), and phenylalanine ammonialyase (PAL), are events related to resistance inducement in plants (Karban \& Myers, 1989). The peroxidases are involved in the processes of lignification (Goodman et al., 1986) and suberization (Bowles, 1990). The polyphenoloxidase enzyme catalizes the oxidation of phenolic compounds to quinones, thus decreasing the nutritional quality of food and reducing its protein digestibility (Felton \& Duffey, 1990; Felton et al., 1994). The in- 
tensification of production of phenolic compounds, known as defense molecules of plants against pathogens and insects, is indicated by an increase in phenylalanine ammonia-lyase activity in wounded plant tissues (Bi \& Felton, 1995). Therefore, the objective of this work was to evaluate the effect of silicon and of previous infestation with aphids on the induction of resistance to the greenbug, Schizaphis graminum (Rondani) (Hemiptera: Aphididae), in wheat plants.

\section{MATERIAL AND METHODS}

Plants and insects - Wheat plants (Triticum aestivum L. cv. Embrapa 42) were grown in greenhouse conditions in 4-kg soil capacity pots for 90 days. All fertilization procedures were performed, based on soil analysis (Malavolta, 1980). Each pot was covered by an organdy fabric cage $(40 \mathrm{~cm}$ width $\times 40 \mathrm{~cm}$ length $\times 80$ $\mathrm{cm}$ height). Moisture in the pots was provided and maintained with daily irrigations. Plants fertilized with calcium silicate received $1.855 \mathrm{~g} \mathrm{~kg}^{-1}$ soil. The calcium silicate contained $62 \% \mathrm{SiO}_{2}$ and $18 \% \mathrm{CaO}$. Plants which did not receive calcium silicate were fertilized with calcium carbonate, $0.61 \mathrm{~g} \mathrm{~kg}^{-1}$ soil. The aphids $S$. graminum were taken from a mass rearing, maintained on variety Lorini wheat plants.

Treatments - Treatments consisted of: 1- zero calcium silicate and absence of aphids (control); 2- fertilization with calcium silicate and absence of aphids; 3- infestation of plants at 30 days after emergence 30 adult aphids per plant for five days, and no calcium silicate fertilization; and, 4- fertilization with calcium silicate plus infestation of plants at 30 days after emergence, 30 adult aphids per plant for five days.

Evaluations were made 35 days after seedling emergency included:

Preference test with leaves removed from wheat plants - Petri dishes $(20 \mathrm{~cm})$ were utilized as arenas. Dishes had bottoms lined with filter paper moistened with distilled water; each dish received one, $8-\mathrm{cm}$ long leaf cut of each treatment, immersed in a $10^{-6} \mathrm{~mol} \mathrm{~L}^{-1}$ benzyladenine solution, inside a $3 \mathrm{~cm}$ long, $0.5 \mathrm{~cm}$ diameter plastic straw, plugged with cotton and randomly arranged side by side. The leaf cut was obtained from the plant's first completely unfolded leaf. Twenty adult aphids were released at straw's opposite side. Dishes were them sealed with perforated plastic film and placed over a lab bench, in an air-conditioned room $\left(26 \pm 2^{\circ} \mathrm{C}\right)$, relative humidity $70 \pm 10 \%$, and 12-hour photophase. Evaluations were performed 24, 48, and 72 hours after releasing the aphids by counting the number of adult aphids and nymphs (removed after counting) on each leaf cut.
Greenbug's rate of population increase - Twenty four hour-old nymphs were individualized in clear, plastic cylindric cages $(1 \mathrm{~cm}$ height; $0.8 \mathrm{~cm}$ in diameter), with the bottom closed with organdy fabric and the rim on the other end padded with foam. Three cages were installed per plant and per pot, and the mean value was later calculated. The method proposed by Wyatt \& White (1977) was utilized to estimate the insect's population increase rate.

Enzymatic activity - Wheat leaves were macerated with a mortar and pestle in the presence of liquid nitrogen, and $10 \mathrm{~mL}$ of phosphate-potassium buffer $\left(0.1 \mathrm{~mol} \mathrm{~L}^{-1} ; \mathrm{pH}\right.$ $6.1)$ were added to $0.2 \mathrm{~g}$ of macerated leaves. After resting for one hour at $4^{\circ} \mathrm{C}$ and periodical agitation, the solution was centrifuged at $13,000 \mathrm{~g}$ for 15 minutes, at $4^{\circ} \mathrm{C}$. Supernatants (enzyme extracts) were then utilized for enzymatic activity determination. Peroxidade (POX) and polyphenoloxidase (PPO) activities were measured by spectrophotometry through the increase in optical density (OD), using $\mathrm{OD}_{470} \min ^{-1} \mathrm{~g}^{-1}$ and $\mathrm{OD}_{420} \min ^{-1} \mathrm{~g}^{-1}$, respectively, following methodology adapted from Silva (2002). The substrates utilized by POX and PPO were guaiacol/ $\mathrm{H}_{2} \mathrm{O}_{2}$, and catechol, respectively. The readings were performed each second, for 2 minutes and the activities were expressed as units per gram of fresh weight $\left(\mathrm{u} \mathrm{g} \mathrm{g}^{-1}\right)$. One activity unit was defined as the increment of 0.1 absorbance unit per minute. To determine the phenylalanine ammonia-lyase (PAL) activity, the enzyme extract was prepared with $1 \mathrm{~g}$ of macerated leaves, $5 \mathrm{~mL}$ tris-HCL $0.1 \mathrm{~mol} \mathrm{~L}^{-1}$ buffer, $\mathrm{pH} 8.8$, and $0.1 \mathrm{~g}$ insoluble polyvinylpyrrolidone. The buffer contained $10^{-3} \mathrm{~mol} \mathrm{~L}^{-1}$ EDTA and $10^{-2} \mathrm{~mol} \mathrm{~L}^{-1} \beta$-mercaptoethanol. After resting for one hour at $4^{\circ} \mathrm{C}$ and periodical agitation, the solution was centrifuged at $1,500 \mathrm{~g}$ for 5 minutes, at $4^{\circ} \mathrm{C}$. The supernatants (enzyme extracts) were utilized for enzymatic activity determination. PAL activity was measured by spectrophotometry through the increase in $\mathrm{OD}_{280} \mathrm{~min}^{-1}$ $\mathrm{g}^{-1}$, following methodology adapted from Data \& Quevedo (1984). The vials containing the reaction mixture were incubated in water bath at $37^{\circ} \mathrm{C}$ for five periods of time $(0,30,60,90$, and 120 minutes), with 0.5 $\mathrm{mL}$ perchloric acid $2 \mathrm{~mol} \mathrm{~L}^{-1}$ utilized to halt the reaction. Activity was expressed as activity units per gram of fresh weight $\left(\mathrm{u} \mathrm{g}^{-1}\right)$. One unit was defined as the amount of trans-cinnamic acid formed per minute under the assay conditions.

Statistics - Four treatments and ten replicates were utilized. Data obtained were submitted to ANOVA, and the means compared by Scott $\&$ Knott test (1974) $(P=0.05)$.

\section{RESULTS}

A reduction in total number of aphids was observed at 48 and 72 hours for treatments in which plants 
were fertilized with silicon. At 72 hours, leaf cuts of plants that received silicon fertilization, or silicon combined with a pre-infestation, were less colonized by aphids (Table 1).

The lowest rate of greenbug population increase $\left(\mathrm{r}_{\mathrm{m}}=0.14\right)$ occurred in the treatment with aphid pre-infestation and silicon fertilization, while the highest population increase was observed in the control $\left(\mathrm{r}_{\mathrm{m}}=0.37\right)$. The rate of $S$. graminum population increase in the treatments with silicon or pre-infestation was intermediate between these two extremes $\left(\mathrm{r}_{\mathrm{m}}=0.25\right.$ and $\mathrm{r}_{\mathrm{m}}=0.23$, respectively) (Figure 1).

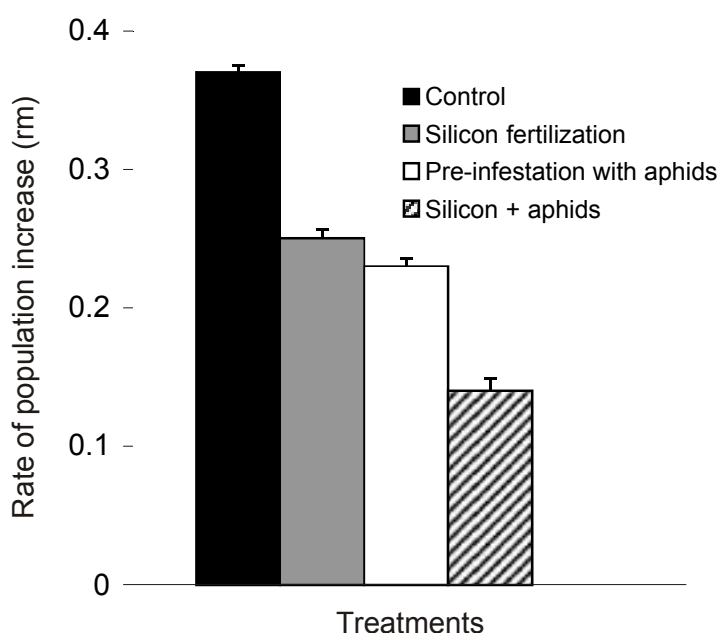

Figure 1 - Rate of population increase $\left(\mathrm{r}_{\mathrm{m}}\right)$ of the greenbug, Schizaphis graminum (mean \pm standard error) in the greenhouse. Bars sharing same letters do not differ by Scott \& Knott test $(P<0.05)$.
The greatest POX activity occurred in the treatment with silicon fertilization and pre-infestation (602 u $\mathrm{g}^{-1}$ fresh weight), followed by the treatments with pre-infestation, and silicon fertilization (441 and $268 \mathrm{u} \mathrm{g}^{-1}$ fresh weight, respectively). All treatments showed higher activities than the control $\left(137 \mathrm{u} \mathrm{g} \mathrm{g}^{-1}\right.$ fresh weight) (Table 2). Treatment silicon fertilization plus pre-infestation (489 $\mathrm{u} \mathrm{g}^{-1}$ fresh weight) showed higher PPO activity than the treatments with silicon fertilization and pre-infestation, which had an intermediate responce (251 and $272 \mathrm{u} \mathrm{g}^{-1}$ fresh weight, respectively), although they were still higher than the control (135 u g ${ }^{-1}$ fresh weight) (Table 2). Only the pre-infestation treatment and the treatment in which silicon fertilization was combined with pre-infestation (0.049 and $0.127 \mathrm{u} \mathrm{g}^{-1}$ fresh weight, respectively) led to an increase in PAL activity, while the treatment with silicon alone did not differ from the control (Table 2).

\section{DISCUSSION}

Pre-infestation with aphids and/or silicon application induce defenses in wheat plants that will affect preference and population increase in $S$. graminum, especially when they act jointly, with cummulative effects. Silicon-fertilized plants present changes in their trichomes (Samuels et al., 1993), as well as in their epidermis and internal tissues (Hodson \& Sangster, 1988). Research on the distribution of silicon indicated that it can be deposited, in the form of silica, in the intracellular spaces, inside the cells, and in the cell wall (Kaufman et al., 1985), as well as in conducting vessels (Hayward \& Parry, 1973).

Table 1 - Total number (mean \pm standard error) of Schizaphis graminum aphids on leaves removed wheat plants.

\begin{tabular}{lcrr}
\hline \multirow{2}{*}{ Treatment } & \multicolumn{3}{c}{ Total number of aphids per leaf } \\
\cline { 2 - 4 } & 24 hours & 48 hours & 72 hours \\
\hline Control & $24.6 \pm 4.04 \mathrm{aA}$ & $35.7 \pm 4.55 \mathrm{aA}$ & $30.6 \pm 1.96 \mathrm{aA}$ \\
Silicon fertilization (SF) & $16.2 \pm 2.95 \mathrm{aA}$ & $11.6 \pm 1.75 \mathrm{bB}$ & $7.3 \pm 1.21 \mathrm{cB}$ \\
Pre-infestation with aphids (PIA) & $15.7 \pm 2.11 \mathrm{aA}$ & $15.9 \pm 2.73 \mathrm{bA}$ & $13.6 \pm 1.71 \mathrm{bA}$ \\
SF + PIA & $17.8 \pm 3.58 \mathrm{aA}$ & $5.0 \pm 1.91 \mathrm{cB}$ & $5.2 \pm 1.84 \mathrm{cB}$ \\
\hline
\end{tabular}

Means followed by a common, lower case letter in the column, and by a common, upper case letter in the row, do not differ by Scott $\&$ Knott test $(P<0.05)$.

Table 2 - Peroxidase (POX), polyphenoloxidase (PPO) and phenylalanine ammonia-lyase (PAL) activities (mean \pm standard error) in wheat plants.

\begin{tabular}{lccc}
\hline \multirow{2}{*}{ Treatment } & \multicolumn{3}{c}{ Enzymatic activity } \\
\cline { 2 - 4 } & POX & PPO & PAL \\
\hline Control & $137 \pm 15 \mathrm{~d}$ & $135 \pm 23 \mathrm{c}$ & $0.017 \pm 0.002 \mathrm{c}$ \\
Silicon fertilization (SF) & $268 \pm 25 \mathrm{c}$ & $251 \pm 20 \mathrm{~b}$ & $0.018 \pm 0.001 \mathrm{c}$ \\
Pre-infestation with aphids (PIA) & $441 \pm 46 \mathrm{~b}$ & $272 \pm 43 \mathrm{~b}$ & $0.049 \pm 0.002 \mathrm{~b}$ \\
SF + PIA & $602 \pm 68 \mathrm{a}$ & $489 \pm 29 \mathrm{a}$ & $0.127 \pm 0.002 \mathrm{a}$ \\
\hline
\end{tabular}

Means followed by a common lower case letter in the column do not differ by Scott \& Knott test $(P<0.05)$.

Sci. Agric. (Piracicaba, Braz.), v.62, n.6, p.547-551, Nov./Dec. 2005 
Results obtained herein might be related to the deposition of silica in the leaf tissue which, by increasing leaf hardness, makes it difficult for the insect's stylet to penetrate the leaf. However, other researches have demonstrated that the application of silicon could change the physiological properties of plants.

Chérif et al. (1994) observed that cucumber plants fertilized with silicon showed an increase in the synthesis of the enzymes peroxidase, polyphenoloxidase, $\beta-1,3$ glucanase, and chitinase, as a response to infection by pathogens. Infection control is possibly related to an intensification of the mechanical barrier and to an accumulation of phenolic compounds, such as lignin, in siliconfertilized plants (Chérif et al., 1992b; Stein et al., 1993). Basagli et al. (2003) reported the non-preference of greenbug nymphs to wheat plants fertilized with sodium silicate; that author also registered reductions in S. graminum longevity and fecundity. The preference and number of nymphs produced by the greenbug were also affected by sodium silicate fertilization in sorghum plants (Carvalho et al., 1999), possibly because of the formation of mechanical barrier resulting from silica deposition in leaf tissue cells. Goussain (2001) verified that corn plants fertilized with sodium silicate were not preferred by the corn leaf aphid, Rhopalosiphum maidis (Fitch) (Hemiptera: Aphididae) compared to the control without silicon.

Silicon could increase the activities of POX and PPO because it triggers defense processes in plants, acting as an elicitor. Regarding PAL, no silicon effect as an activator of this enzyme was observed. However, an additive effect occurred in plants fertilized with silicon and pre-infesteded with aphids. Probably this could be related to the fact that defense responses depend on factors such as the velocity of expression, type, and concentration of the elicitor, plant utilized, and duration of the protective effect (Roncatto, 1998).

Plant's defense system is activated by previous infestation of insects, silicon fertilization, or both. Silicon, alone or together with pre-infestation, negatively affected the greenbug's preference and population increase rate, and provided a significant increase in the activities of POX, PPO, and PAL. Peroxidase is related to lignin and suberin synthesis, which increase the hardness of tissues, and to the production of quinones and active oxygen, which possess antibiotic properties (Goodman et al., 1986; Bowles, 1990; Stout et al., 1994). In addition to being involved in the lignification process, PPO is also responsible for the oxidation catalysis of phenols to quinones, which become complexed with proteins, thus decreasing the nutritional quality of food, making protein digestion difficult (Felton \& Duffey, 1990; Felton et al., 1994; Mohammadi \& Kazemi, 2002). Phenylalanine ammonia-lyase is related to the synthesis of phenolic compounds with deterrent, toxic and antinutritional properties (Appel, 1993). Therefore, an increase in the activity of these enzymes indicates the synthesis of plant defense compounds against external agents.

\section{ACKNOWLEDGEMENTS}

To Universidade Federal de Lavras and Fundação de Amparo à Pesquisa do Estado de Minas Gerais (FAPEMIG) for making this research work possible, and to Conselho Nacional de Desenvolvimento Científico e Tecnológico $(\mathrm{CNPq})$ for granting a scholarship.

\section{REFERENCES}

APPEL, H.M. Phenolics in ecological interactions: the importance of oxidation. Journal of Chemical Ecology, v.19, p.1521-1552, 1993.

BASAGLI, M.A.B.; MORAES, J.C.; CARVALHO, G.A.; ECOLE, C.C.; GONÇALVES-GERVÁSIO. R. de C.R. Effects of sodium silicate application on the resistance of wheat plants to the green-aphid Szhizaphis graminum (Rond.) (Hemiptera: Aphididae). Neotropical Entomology, v.32, p.659-663, 2003.

BI, J.L.; FELTON, G.W. Foliar oxidative and insect herbivory: primary compounds, secondary metabolites, and reactive oxigen species as components of induced resistance. Journal of Chemical Ecology, v.21, p.1511-1530, 1995.

BOWLES, D.J. Defense-related proteins in higher plants. Annual Review of Biochemistry, v.59, p.873-907, 1990.

CARVALHO, S.P.; MORAES, J.C.; CARVALHO, J.G. Efeito do silício na resistência do sorgo (Sorghum bicolor) ao pulgão verde Schizaphis graminum (Rond.) (Hemiptera: Aphididae). Anais da Sociedade Entomológica do Brasil, v.28, p.505-510, 1999.

CHÉRIF, M.; BENHAMOU, N.; MENZIES, J.G.; BÉLANGER, R.R. Silicon induced resistence in cucumber plants against Pythium ultimum. Physiological and Molecular Plant Pathology, v.41, p.411-425, 1992a.

CHÉRIF, M.; MENZIES, J.G.; BENHAMOU, N.; BÉLANGER, R.R. Studies of silicon distribution in wounded and Pythium ultimun infected cucumber plants. Physiological and Molecular Plant Pathology, v.41, p.371-383, 1992b.

CHÉRIF, M.; ASSELIN, A.; BÉLANGER, R.R. Defense responses induced by soluble silicon in cucumber roots infected by Pythium spp. Phytopathology, v.84, p.236-242, 1994.

DATA, E.S.; QUEVEDO, M.A. Prunning techniques affecting the root quality of cassava at harvest and subsequent storage. In: TERRY, E.R. Tropical root crops: postharvest physiology and processing. Ottawa: IDRC, 1984. p.127-143.

DIXON, R.A.; HARRISON, M.J.; LAMB, C.J. Early events in the activation of plant defense responses. Annual Review of Phytopathology, v.32, p.479-501, 1994.

EPSTEIN, E. The anomaly of silicon in plant biology. Proceedings of the National of Academy of Science of the USA, v.91, p.11-17, 1994.

EPSTEIN, E. Silicon. Annual Review of Plant Physiology and Plant Molecular Biology, v.50, p.641-664, 1999.

FAWE, A.; ABOU-ZAID, M.; MENZIES, J.G.; BÉLANGER, R.R. Siliconmediated accumulation of flavonoid phytoalexins in cucumber. Phytopathology, v.88, p.396-401, 1998.

FELTON, G.W.; DUFFEY, S.S. Inactivation of baculovirus by quinones formed in insect-damaged plant tissues. Journal of Chemical Ecology, v.16, p.1221-1236, 1990.

FELTON, G.W.; SUMMERS, C.B.; MUELLER, A.J. Oxidative responses in soybean foliage to herbivory by bean leaf beetle and three-cornered alfalfa hopper. Journal of Chemical Ecology, v.20, p.639-650, 1994.

GOODMAN, R.N.; KIRALY,Z.; WOOD, K.R. Secondary metabolite. In: GOODMAN, R.N. The biochemistry and physiology of plant disease. Missouri: University of Missouri, 1986. p.211-224.

GOUSSAIN, M.M. Efeito da aplicação do silício em plantas de milho no desenvolvimento biológico da lagarta-do-cartucho Spodoptera frugiperda (J. E. Smith) e do pulgão-da-folha Rhopalosiphum maidis (Fitch, 1856) (Hemiptera: Aphididae). Lavras: UFLA, 2001. 63p. (Dissertação - Mestrado). 
HAYWARD, D.M.; PARRY, D.W. Eletron-probe microanalysis studies of silica distribuition in barley (Hordeum sativum L.). Annals of Botany, v.37, p.579-591, 1973.

HODSON, M.J.; SANGSTER, A.G. Observations on the distribution of mineral elements in the leaf of wheat (Triticum aestivum L.), with particular reference to silicon. Annals of Botany, v.62, p.463-471, 1988.

KARBAN, R.; MYERS, J.H. Induced plant responses to herbivory. Annual Review of Ecology and Systematics, v.20, p.331-348, 1989.

KAUFMAN, P.B.; DAYANANDAN, P.; FRANKLIN, C.I. Structure and function of silica bodies in the epideramal system of grass shoots. Annals of Botany, v.55, p.487-507, 1985.

MALAVOLTA, E. Elementos de nutrição mineral de plantas. São Paulo: Ceres, 1980. 251p.

MOHAMMADI, M.; KAZEMI, H. Changes in peroxidase and polyphenol oxidase activies in susceptible and resistant wheat heads inoculated with Fusarium graminearum and induced resistance. Plant Science, v.162, p.491-498, 2002.

RONCATTO, M.C; PASCHOLATI, S.F. Changes in activity and electrophoretic pattern of peroxidase in maize (Zea mays) and sorghum (Sorghum bicolor) leaves treated with yeast (Saccharomyces cerevisae). Scientia Agricola, v.55, p.395-402, 1998.

SAMUELS, A.L.; GLASS, A.D.M.; EHRET, D.L.; MENZIES, J.G. The effects of silicon supplementation on cucumber fruit: changes in surface characteristics. Annals of Botany, v.72, p.433-440, 1993.
SCOTT, A.J.; KNOTT, M.A. A cluster analysis method for grouping means in the analysis of variances. Biometrics, v.30, p.507-512, 1974.

SILVA, L.H.C.P. Resistência sistêmica ativada pelo acibenzolar-s-metil contra doenças em tomateiro. Lavras: UFLA, 2002. 89p. (Dissertação Mestrado).

STEIN, B.D.; KLOMPARENS, K.L.; HAMMERSCHMIDT, R. Histochemistry and ultrastructure of the induced resistance of cucumber plants of Colletotrichum lagenarium. Journal of Phytopathology, v.137, p.177-188, 1993.

STOUT, M.J.; WORKMAN, J.; DUFFEY, S.S. Differential induction of tomato foliar proteins by arthropod herbivores. Journal of Chemical Ecology, v.20, p.2575-2594, 1994.

WYATT, I.J.; WHITE, P.F. Simple estimation of intrinsic increase rates for aphids and Tetranychid mites. Journal of Applied Ecology, v.14, p.757766, 1977

YOSHIDA, S.; OHNISHI, Y.; KITAGISHI, K. Histochemistry of silicon in rice plant. Soil Science and Plant Nutrition, v.8, p.107-111, 1962.

Received October 01, 2004

Accepted November 03, 2005 